\title{
The Effect of Non-Monetary Framing Sales Promotion on Customer's Purchase Intention with Believability of the Deal Offer As Mediation Variables
}

Nurainun, Jasman J. Ma'Ruf, Mirza Tabrani, and M. Shabri Abd. Madjid

\section{Abstract}

This research aims to analyze the effect of different promotion frame with the same value (framing sales promotion) on customer purchase intention for famous brand cosmetic products with expensive price. Believability of the deal offer variable assumed as intermediating the effect of framing sales promotion on customer purchase intention. The previous study result mentioned that promotion which cannot be trusted (too good to be true) will make the customer uninterested towards offered promotion.

Corresponding Author:

Nurainun

ainunsamka@gmail.com

Received: 18 January 2019

Accepted: 24 March 2019

Published: 31 March 2019

Publishing services provided by

Knowledge E

(c) Nurainun et al. This article is distributed under the terms of the Creative Commons.

Attribution License, which permits unrestricted use and redistribution provided that the original author and source are credited.

Selection and Peer-review under the responsibility of the First ELEHIC Conference Committee.
Furthermore, the believability of the deal offer from promotion framings is still rarely studied although the research limitation mentioned that the credibility of a promotion is an important thing to be tested and potential variable is a kind of media for identifying a relationship between framing effect and customer purchase intention. Previous research more often conducted on a form of monetary promotion such as discount promotion while research on non-monetary promotions is still rarely done. Design experiment method three (free gift, buy two Get one free, extra content) x one (famous brand) between subject factorial design are implemented for collecting data. Data collection was performed on career women and housewives. Data analysis technique will be using One Way ANOVA, while ANCOVA will be used to test the mediation effect of believability of the deal offer.

Keywords: framing sales promotion, non-monetary promotion, purchase intention, believability of the deal offer, experiment

\section{Introduction}

The study of this research aims to examine the differences in the effect of non - monetary sales promotion form that are framed differently but have equivalent value for hedonic products, as well as to identify their impact on customer purchase intentions. The reason 
monetary promotional research is often conducted by researchers but little attention is given to non-monetary promotional research [1-4]. Most of the researchers examined the effect of this form of price promotion alone (percentage off vs cent off), or compare between non-monetary price promotions such as discounts with the extra product, discount with premium (gift). Previously have examined different promotional frames with the same value for utilitarian products and identified their effects on transaction value perceptions, not testing the intention of customer purchase intention [5].

As we know, marketers often use forms of sales promotion as a tool to drive purchase intentions and increase sales. The forms of promotion used are often different forms, with the aim that customers have their own value perceptions based on the evaluation they are doing, on each form of the campaign or promotion. Each of these forms of promotion (framing promotion) is believed to have a different impact on customers when they evaluate the type of promotion (based on profit or loss perceived) and ultimately affect their behavior. Sales promotions such as discounts, coupons, rebates, extra products, extra contents, and premiums are promotional forms intended for consumers (consumer promotion). Different forms of consumer promotions are framed in different forms and are often found in retailers or shopping centers, such as percent off discounts and cent off, extra product promotions, extra content promotions can be framed within shaped like buy one get one free or 50 percent discount, 50 percent more content, free gift and soon, and there are also promotional forms merged like buy two get 50 percent off, all of it done by marketers to influence consumer behavior such as purchase intention.

Customers targeted by marketers with such diverse promotional frames will evaluate the value offered by the promotion, the value consists of transaction value and acquisition value [6, 7]. Thaler [7] also mentioned that customers will evaluate the value based on the profit and loss they will get from a promotional offer (mental accounting). Value evaluation is an early stage that will lead consumers to the decision of choosing an offer that gives the highest expectations expected by the customer, and then raises the intention of purchase.

A study by Chandon, et al. [8] found that monetary promotion was more suitable for utilitarian products (giving utilitarian benefits), whereas non-monetary promotions were more suitable for hedonic products (giving hedonic benefits). Although in this research the researchers examined the promotional frames in hedonic products, the researchers did not examine the hedonic benefits perceived by customers from non-monetary promotions. The cosmetic product is a type of hedonic product that also often uses various forms of promotion as previously mentioned, but the famous cosmetic brand with high 
brand equity usually does not use excessive forms of promotion and also not routinely promoted, in order to not arouse suspicion for the consumer. Therefore, even in the short term sales promotions can increase sales quickly as long-term sales promotion is believed to damage brand equity [9]. So marketers should be able to choose a form of promotion that matches the product brand but does not reduce brand equity. In addition, sales promotions especially discount promotions will make customers sensitive to the price, making them buy the product only when it is a promotion given [10].

In addition to evaluating the perceived value of the customer for these promotional forms, there is another factor that the customer considers to influence whether the customer is willing to buy or not, which also means whether the offer of the promotion is trustworthy (believability). Believability of a promotional offer is an important thing that should be investigated by marketers. The promotion value that overly good (too good to be true) can cause suspicion from consumers [11]. Ong, et al.[12] in his study evaluating the impact of extra content promotional form (extra pack) and the discount promotion on purchase intentions, perceptions of value, believability of the deal offer and perceptions of manufacturers found that promotional value too high (extra content of 60 percent versus 80 percent) make consumers suspicious, and convinced with the extra content of the 60 percent along with better perceived value, and cause consumer purchase intention.

Believability of a promotional form has been studied by Ong, et al. [12] but Ong, et al. [12] merely identify the believability of extra-content promotional forms and price discounts $(60$ percent extra content vs. 80 percent extra content and 20 percent discount) and the promotional value is unequal and does not treat itself as a mediating variable. However, Ong [13] mentioned that a form of trustable promotion (believability) by consumers will increase the perception of value and then will increase consumer purchase intentions. Compeau and Grewal [14] also tested the believability of the price offer in their study of comparative price advertising, investigating the effects of reference price advertising, reference price level advertising, selling price ads on internal consumer reference prices, perceived value, price offer believability, purchase intention and search intention. Chang [11] only identified ad believability of premium value and its effect on brand attitudes. While Diamond [15] has stated that the credibility of a form of promotion is very important, and there is a very few research on the credibility of a form of promotion. This refers to the results of a study by Campbell and Diamond [16] who found that large discounts were less reliable than large non-monetary promotions. Palazon and Delgado-Ballaster [17] in their suggestions for future research mentioned about to test the believability of the deal offer because consumers can be suspicious of the deal 
offer offered by marketers. Similarly, Kim and Kramer [18] in one of his suggestions for future research is to test the believability of the entire price offer that can affect the value of the transaction.In this research, plan researchers will compare three non-monetary promotional frames namely extra content, extra products, and premium. The reason for researchers to use these three types of promotion because each non-monetary promotion difference in previous research was in a form of extra content, extra product and premium with equivalent values have not been used at once and identify their effect on purchase intention. If in the previous study the framing effect comparison of the promotion was applied to low priced product and high priced product [19-23], then different forms of promotion are applied in this research plan to high priced products with famous brand names, because brand names affect consumers when evaluating a promotion [24, 25]. Previously Swani and Yoo [26] have identified the impact of discount promotion (price deals) on purchasing intentions, applied to well-known brands with high equity brands such as Prada handbags and sunglasses, but they do not identify the framing effect of the price deals (comparing discounted and undiscounted brands). The effects of each of these promotional forms will be tested on the purchase intention and believability of the promotional offer.

Therefore, in this study the author would compare the effects of non-monetary promotions that are framed differently but have an equivalent value, and identify the effect on purchase intention of the customers and also compare which promotional frames are more trusted by the customer as well as identify the mediation effect of the believability of the deal offer that is predicted to mediate the relationship between non-monetary promotional frames with the purchase intention of the customers.

\section{Literature Review}

\subsection{Framing effect, monetary and non-monetary promotion}

Framing is one of the cores of prospect theory initiated by Kahneman and Tversky [27], which stated that the same decision choices can be displayed differently and consumers will evaluate those choices based on the gains and losses perceived. Based on the theory of the prospect then the forms of sales promotion can be described in various ways such as discount promotions in the form of a percentage, rupiah value or framed in the form of promotional rewards such as buy two get one free, free gift, or extra contents.

The framing process shows that different promotions of the same value can be perceived differently as gains or reduced loss. The approach that predicts framing sales 
promotion considers the degree of effort necessary that integrates promotional benefits with pricing information. When a promotion is made in a monetary unit such as a discount, the promotion will be integrated with the price. So the promotion will be framed as a reduced loss. Otherwise, if the promotion is performed in non-monetary units such as free goods then the benefits of such promotions are difficult to integrate with prices and promotions like this are often considered as separate gains. The benefits of the promotion that perceived as gains are separated from the real reference price while the reduced loss is linked to the reference price. This phenomenon explains that promotions considered as a reduced loss will have an impact on reference prices rather than on promotions perceived as gains [28].

Therefore experts group the forms of sales promotion into non-monetary promotions such as extra products and premiums that are perceived as gains separate from the reference price, and monetary promotions such as discounts and rebates that affect reference prices $[8,16,28]$. Monetary and non-monetary promotions have several differences and have complementary functions (overlapping function). Monetary promotion affects behavioral goals while non- monetary promotions affect affectively and behaviorally. The decision to select the promotional forms to be used is influenced by whether the option (promotional form) is formed as a gain (framed as gain) or as a reduced loss.

Promotion forms that framed differently are evaluated based on the perceived value of the consumer. The perception of value consists of the value of the acquisition and the value ofthe transaction $[6,7]$. The value of the acquisition is a comparison between the benefits with the money spent to obtain the product, while the value of the transaction is the consumer's evaluation that only on the transaction of the given promotion. The value of the acquisition relates to the quality of a product brand.

Results of studies conducted by some previous researchers such as Chen, et al. [19] found that discounted promotional frames in percentages are more suitable for lowpriced products whereas promotional frames in the form of nominal values are more suitable for high-priced products. The study results of Chen, et al. [19] is supported by a study conducted by Gendal, et al. [20] who found the same thing, but Gendal, et al. [20] compared more diverse forms of promotion and also found that the buy two get one free form was more interesting than the three for the price two promotion. Sinha and Smith [5] compare three different types of promotion but with the same value of 50 percent off, buy one get one free and buy two get 50 percent off, promotion is done on utilitarian products such as bread and cheese (high price) toilet paper and liquid detergent for low price products. In his study, consumers perceive 50 percent discount is the most interesting form, followed by buy two get one free then buy two get 50 percent off. From 
these results, it can be concluded that different promotional frames can be perceived differently by consumers and this is also affected by the nature and type of product [16].

In choosing a premium promotion (free gift), the company must be able to identify premiums that appeal to consumers not just giving a gift. Although the hypothesis proposed by Seipel [29] that the more consumers do not demand a reward the gift should be attractive is not supported. A study conducted by Buil, et al. [4] mentions the opposite; premium attractiveness is the greatest factor affecting consumer evaluation when evaluating the promotion with premium forms, followed by brand attitudes toward promoted brands, the suitability of prizes with promoted products, product hedonic properties, value expression and entertainment benefits.

\subsection{Purchase intention}

The purchase intention or willingness to buy is defined by Dodds, et al. [30] as the possibility that the buyer intends to buy a product. Purchase intention is a preliminary evaluation of the consumer when they have evaluated a product brand that has the highest value [31].

Some research results on the effects of promotional forms (monetary or nonmonetary) that have been reviewed by researchers have found that promotional forms have diverse effects on consumer purchase intentions [3, 12, 17-19, 22-24, 26, 32-37]. Although the results of the study of Chen et al. [19] found that the form of percentage promotion more appropriate for low-priced products and cent-off is more appropriate for high-priced products but does not cause purchase intentions for consumers, this is due to the small promotional value. But a study conducted by Ong, et al. [12]) found that the value of a large promotion does not cause consumer purchase intention, which is caused by consumer suspicion of the promotion value. A study conducted by Palazon and Delgado-Ballaster [17] found that the promotion form (discount vs. premium) did not have a different effect on customer purchase intention. While in the study Buil, et al. [4] states that the consumer evaluation towards the gift suitability with the product being promoted is one of the factors that influence the consumer purchase intention.

\subsection{Believability of the deal offer}

Consumers often underestimate the promotional value provided by the promotion [24], it is because the value of saving is too small so that consumers are not interested in the 
offered promotions. But oversized promotional value can also make consumers suspicious [11, 12], consumers who do not believe in the promotional value offered will cause a negative attitude to the brand, making it a trade-off for marketers to determine the proper form of promotion in orderto influence consumer purchase intentions. Furthermore, promotions in the form of prizes must be able to generate consumer confidence so that the gift is perceived to have good value and suitable with the promoted product. The study result conducted by Raghubir [25] mentioned that consumers perceive the price of a gift (free gift) is cheap when the price of the prize is not displayed and the brand of the gift is unknown, and when the gift is sold consumers will buy at a low price. When this happens then the consumer will not be interested and believe that the gift is attractive. This fact is corresponding with the statement by Simonson, et al. [38] that the promotion can be backfired when consumers prefer to buy products when they are not promoted. Because consumers regard that the quality of the prize product lowers than the promoted one. And when the product used as a gift is sold then consumers perceive it as an inferior product. Premium value (free gift) that perceived less trusted by consumers will negatively impact on brand attitudes, thereby decreasing consumer purchase intentions [11].

The fair promotional value must be at the limit of the latitude of acceptance, but the value of the promotion should also get the attention of the consumer that there is a difference assessed by the customer such as the deviation between the selling prices after the reduced price promotion (just noticeable difference). The highly small promotion value makes consumers unaware of the provided promotion. In a study conducted by Campbell and Diamond [16] about a good promotional frame, they illustrate that high promotional value makes consumers suspicious, low promotional value make consumers do not care, the most appropriate is to be among a range of the latitude of acceptance. In non-monetary promotional studies such as premium promotional frames or extra products should pay attention to the value of the gift and this is an important thing. Since the customer will evaluate the value of the product that will be given, the price of the gifted product should be displayed so that the customer will perceive the exact value. Therefore, choosing gifts or extra products for non-monetary promotions is essential to consider the suitability of the gift with the promoted product (gift fit product), the gift attractiveness and the nature of the promoted product (hedonic or utilitarian), as those are the factors that are evaluated by consumers and influence their behavior. 


\subsection{Hypothesis}

Based on the theoretical background that has been presented, the hypothesis drawn as follows:

H1: Non-monetary promotional frames (buy two get one free, extra content, free gift) have different effects on purchase intention

$\mathrm{H} 2$ : Non-monetary promotional frames (Buy two get one free, extra content, and free gift) have different of believability of the deal offer.

H3: Believability of the deal offer mediates the relationship between the promotional frame and the consumer purchase intention

\section{Research Methodology}

The research design used was experimental three (buy two get one free, extra content, free gift) $x$ one (famous brand) between the subject factorial designs. A form of experiment used is a paper and pencil experiment in the form of promotional brochures. A preliminary study was conducted to determine the type of cosmetic product and brand to be used. Manipulation will be done on three forms of promotion such as free gift, B2G1F and extra contents. Data collection was done in an experimental laboratory conducted on career women and housewives. This is because the products that purchased are expensive cosmetics products, so career women and housewives are the right participants for this study, while students is used as participants in the previous studies.

The validity testing of the dependent variable will uses factor analysis called confirmatory factor analysis, and reliability testing are using Cronbach alpha. Meanwhile, the validity testingfor the independent variables is performed by preliminary study and manipulation check. A preliminary study was conducted to identify the types and brands of cosmetic products to be used in the study. In addition, it is also conducted to identify the level of promotion used, to identify a premium fit product and to identify the appeal of prizes (for premium forms and extra products). A preliminary study was conducted by survey method, the respondents were career women and housewives, but they were not participants in the experiment to avoid biased. Data analysis methods will use One Way Anova and Analysis of covariance. One Way Anova is used to identify and analyze differences in the influence of promotional forms on purchase intention, while Analysis of covariance is used to identify and analyze the mediation effects of the believability of the deal offer variables. 


\section{References}

[1] Jones, J. M. (2008). An Exploratory Study on Attitude Persistence Using Sales Promotions, Journal of Managerial Issues, vol.20, no.3, pp.401-416.

[2] D’Astous, Alain. and Jacob, Isabella. (2002). Understanding Consumer Reactions to

[3] Montaner, T. Chernatoni, L. de. and Buil, Isabel. (2011). Consumer Response to Gift Promotion, Journal of Product \& Brand Management, vol. 20, no, 2, pp.101-110.

[4] Buil, Isabel. Chernatony, L. de. and Montaner, Teresa. (2013). Factors Influencing Consumer Evaluations of Gift Promotions. European Journal of Marketing, vol. 47, no. $3 / 4$, pp. 574-595.

[5] Sinha, Indrajit. and Smith, M.F. (2000. Consumers Perceptions of Promotional Framing of Price, Psychology \& Marketing, vol. 17, no. 3, pp. 257- 275.

[6] Thaler, H.R. (1983), Mental Accounting and Consumer Choice, Marketing Science, vol. 4, no. 3, pp. 139-2214.

[7] Monroe, K.B. and Chapman, J.D. (1987). Framing Effects on Buyer's Subjective Product Evaluation, Advances in Consumer Research, vol.14, pp.193-197.

[8] Chandon, P. Wansink, B. and Laurent, G. (2000). A Benefit Congruency Framework of Sales Promotion Effectiveness, Journal of Marketing, vol. 64, no. 4, pp. 65-81.

[9] Yoo, Boonghe. Dongthu, Naveen., and Lee, Sungho. (2000). An Examination of Selected Marketing Mix Elements and Brand Equity, Journal of the Academy of Marketing Science, vol. 28, no. 2, pp. 195-211.

[10] Mela, Carl, F. Gupta, Sunil. and Lehman, Donal. R. (1997). The Long-Term Impact of Promotion and Advertising on Consumer Brand Choice, Journal of Marketing Research, vol. 34, no. 2, pp. 248-261.

[11] Chang, Chingching. (2009). Effectiveness of Promotional Premiums: The Moderating Role of Affective State in Different Contexts, Psychology \& Marketing, vol. 26, no. 2, pp. 175-194.

[12] Ong, Beng Soo. Nin Ho, Foo. Tripp, Carolyn. (1997). Consumer Perceptions of Bonus Packs: An Exploratory Analysis, Journal of Consumer Marketing, vol.14, no. 2, pp. 102-112.

[13] Ong, Beng Soo. (1999). Determinants of Purchase Intentions and Stockpiling Tendency of Bonus Packs, American Business Review, pp. 57-64.

[14] Compeau, Larry D. and Grewal, Dhruv. (1998). Comparative Price Advertising: An Integrative Review, Journal of Public Policy \& Marketing, vol.17, no. 2, pp. 257-273. Premium-Based Promotional Offer, European Journal of Marketing, vol. 36, no. 11/12, pp. 1270-1286. 
[15] Diamond, W.D. (1992). Just What is a" Dollar's Worth"? Consumer Reaction to Price Discount vs Extra Product Promotions, Journal of Retailing, vol. 68, no.3, pp. 254-270.

[16] Campbell, Leland. and Diamond, W. D. (1990). Framing and Sales Promotions: The Characteristics of a Good Deal, Journal of Consumer Marketing, vol.7, no.4, pp. 2531

[17] Palazon, Mariola. and Delgado-Ballaster, Elena. (2009a). Effectiveness of Price Discount and Premium Promotion, Psychology \& Marketing, vol. 26, no. 12, pp. 11081129

[18] Kim, Min Hyeong. and Kramer, Thomas. (2006). Pay $80 \%$ versus "get $20 \%$ off: The Effect of Novel Discount Presentation on Consumers' Deal Perceptions, Market Lett, vol. 17, pp. 311-321.

[19] Chen, S.F. Monroe, K.B. and Lou, Y.C. (1998). The Effects of Framing Price Promotion Messages on Consumers' Perceptions and Purchase Intentions, Journal of Retailing, vol. 74 , no.3, pp. 353-372.

[20] Gendal, Philip., Hoek, Janet. Pope, Tracy. and Young, Karen. (2006). Message Framing Effects on Price Discounting, Journal of Product \& Brand Management, vol. 15, no.7, pp.458-465.

[21] Weisstein, Fei Lee. and Monroe, Kent B. (2009). Promotion Framing Effects on Consumers' Perceptions of Customized Pricing, Extended abstract in Advances in Consumer Research, vol. 36, pp.716-717.

[22] Choi, Choongbeom. and Mattila, Anna. S. (2014). The Effects of Promotion Framing on Consumers' Price Perceptions: The Moderating Role of a Personal Sense of Power, Journal of Service Management, vol. 25, no.1, pp. 149-160.

[23] McKechnie, Sally. Devlin, James. Ennew, Christine. and Smith, Andrew. (2012). Effects of Discount Framing in Comparative Price Advertising, European Journal of Marketing, vol. 46, no. 11/12, pp. 1501-1522.

[24] Gupta, Sunil. and Cooper, L.G. (1992). The Discounting of Discount and Promotion Threshold, Journal of Consumer Research, vol. 19, pp. 401-411.

[25] Raghubir, Priya. (2004). Free Gift with Purchase: Promoting or Discounting the Brand?", Journal of Consumer Psychology, vol. 14, no. 1\&2, pp. 181-185.

[26] Swani, Kunal. and Yoo, Boonghee. (2010). Interaction between Price and Price Deal, Journal of Product \& Brand Management, vol. 19, no. 2, pp. 143-152.

[27] Kahneman, D. and Tversky, A. (1979). Prospect Theory: An Analysis of Decision Under Risk. Econometric, vol. 47, pp. 263-291. 
[28] Diamond, D. William, and Johnson, R. Robert. (1990). The Framing of Sales Promotions: an Approach to Classification, Advances in Consumer Research, vol. 17.

[29] Seipel, C.M. (1971). Premiums - Forgotten by Theory, Journal of Marketing, vol. 32, no. 2 , pp. $26-34.143-15$

[30] Dodds, W.B. Monroe, K.B. and Grewal, D. (1991).The Effects of Price, Brand name, and Store Information on Buyers Perceptions of Product Evaluations, Journal of Marketing Research, vol. 28, no. 3, pp. 307-319.

[31] Assael, Henry. (2001). Consumer Behavior and Marketing Action. New York, South Western College.

[32] Grewal, D. Monroe, K.B. and Krishnan, R. (1998)a. The Effects of Price-Comparison Advertising on Buyers' Perceptions of Acquisition value, Transaction Value and Behavioral Intention, Journal of Marketing, vol.62, No.2, pp.46-59.

[33] Grewal, D. Krishnan, R. Baker, Julie. and Borin, Norm. (1998)b. The Effects of Store Name, Brand Name and Price Discount on Consumers' Evaluations and Purchase Intention, Journal of Retailing, vol. 74, no.3, pp.331-325.

[34] Munger, L.J. and Grewal, D.(2001). The Effects of Alternative Price Promotional Methods on Consumers' Product Evaluations and Purchase Intentions, Journal of Product \& Brand Management, vol.10, no, 3, pp. 185-197.

[35] Devlin, James. Ennew, Chistine. McKechnie, Sally. and Smith, Andrew. (2007). A Study of Time Limited Price Promotions, Journal of Product \& Brand Management, vol. 16, no. 4 , pp. $280-285$.

[36] Palazon, Mariola. and Delgado-Ballaster, Elena. (2009b). The Moderating of Price Consciousness on the Effectiveness of Price Discount and Price Premium Promotions, Journal of Product \& Brand Management, vol. 18, no, 4, pp.306-312

[37] Lowe, Ben. (2010). Consumer Perceptions of Extra Free Product Promotions and Discount: the Moderating Role of Perceived Performance Risk, Journal of Product \& Brand Management, vol. 19, no.7, pp. 496-503.

[38] Simonson, I. Carmon, Z. and O, Curry, S. (1994). Experimental Evidence on The Negative Effect of Product Features and Sales Promotion on Brand Choice, Marketing Science, no. 13, pp. 23-40. 